length of the penis bag and their correlation; Ph. fontinalis and Phys. acuta are reliably differentiated with spermatheca and oviduct parameters.

Key words: Physinae, reproductive system, multivariate statistics, copulative apparatus.

Стаття надійшла до редколегії 16.02.2015 p.

УДК 595.771

Наталія Кілочицька, Ольга Стеценко

\title{
Зміни кількісного та якісного складу антропофільних видів кровосисних комарів Канівського природного заповідника
}

Аналіз ентомологічних зборів Канівського природного заповідника за 2006 та 2015 рр. показав суттєві відмінності в чисельності (домінуючий у 2006 р. Aёdes vexans поступився місцем у 2015 р. Culex modestus) i видовому складі (уперше на території заповідника відзначено Culiseta alaskaensis) антропофільних видів кровосисних комарів. Ці відмінності обумовлені суттєвою різницею гідрологічного й температурного режимів у ці роки, що, зі свого боку, зумовило різну кількість і тип куліцидогенних водойм на території заповідника.

Ключові слова: кровосисні комарі; кліматичні зміни; Канівський природний заповідник.

Постановка наукової проблеми та ії̈ значення. Канівський природний заповідник - база проведення літньої навчальної практики студентів. У середньому протягом половини року в межах заповідника перебуває понад тисяча осіб. Одним із факторів потенційної небезпеки виступають кровосисні комарі - докучливі кровососи та переносники паразитарних інвазій, вірусних і бактеріальних інфекцій. Ключову роль у життєвому циклі комарів відіграють чинники природного середовища коливання зимових та літніх температур, сонячної радіації, вологості, ступеня мінералізації водойм, наявності джерела живлення - хазяїв, екстремальні відхилення яких від оптимуму негативно впливають на чисельність комарів. Такі фактори, як опади й вітер, механічно впливають на літ імаго та розвиток личинок комарів у водоймах.

Мета та завдання дослідження. Мета статті - визначення факторів, які спричиняють зміни чисельності та видового складу в популяціях кровосисних комарів Канівського природного заповідника. Завдання роботи - визначення видового складу антропофільних комарів, визначення видівдомінантів, аналіз кліматичних умов досліджуваних періодів, установлення причин змін чисельності й видового складу комарів у зборах за 2006 та 2015 pp.

Матеріали й методи дослідження. Матеріал зібраний на території Канівського природного заповідника методом «збору на собі» (відлов протягом 30 хв, обліки - двічі на добу протягом 36 діб) на контрольних ділянках [5]. Збір комарів у приміщеннях проводили за допомогою ексгаустера. Визначення самок імаго здійснено з використанням визначника А. В. Гуцевич, А. С. Мончадський, А. А. Штакельберг [1].

Індекс домінування Бергера-Паркера визначали за формулою [4]:

$$
D i=n i / N \cdot 100 \text {, }
$$

де: $n i$ - кількість особин аналізованого виду; $N$ - загальна кількість особин комарів у вибірці.

Виклад основного матеріалу й обгрунтування отриманих результатів дослідження. Для 3'ясування можливих причин змін чисельності та видового різноманіття антропофільних видів комарів у регіоні нами проведено порівняльний аналіз цих показників у 2006-му та 2015 рр. на фоні суттєвих відмінностей кліматичних умов.

Характерними особливостями кліматичних умов 2006 р. були холодна, затяжна й сніжна зима та велика кількість опадів протягом теплого періоду року (рис. 1,2). Це спричинило, насамперед, появу навесні великої кількості тимчасових і напівпостійних водойм (заповнені талою водою канави, вирви, пониження берегової смуги річок, заболоченості тощо) та, як наслідок, сплеску чисельності й

(C) Кілочищька Н., Стецеенко О., 2015 
видового різноманіття приурочених до цих водойм моноциклічних весняних видів комарів із родів Aedes та Ochlerotatus, що інтенсивно нападали на людей. Саме тому цього року серед 17 зареєстрованих антропофільних видів комарів із 3-х родів [3] домінуючі позиції зайняли чотири види комарів, які належать до двох екологічних груп (табл. 1).

Передусім, це моноциклічні види роду Ochlerotatus, що зимують у фазі яйця: ранньовесняний $O$. cataphylla та пізньовесняні $O$. cantans і $O$. diantaeus; а також зимуючий у фазі яйця поліциклічний Ae. vexans.

Табличя 1

\section{Перелік видів антропофільних комарів, домінуючих у різні роки на території Канівського природного заповідника}

\begin{tabular}{|l|c|c|}
\hline \multirow{2}{*}{\multicolumn{1}{|c|}{ Вид }} & \multicolumn{2}{|c|}{ Індекс домінування (Di), \% } \\
\cline { 2 - 3 } & кінець весни-літо 2006 р. & кінець весни-літо 2015 p. \\
\hline Culex modestus Fic & - & 31,4 \\
\hline Aëdes vexans (Mg.) & 29,0 & 20,9 \\
\hline Culiseta alaskaensis (Ludl.) & - & 16,3 \\
\hline Ochlerotatus cantans Mg. & 21,8 & - \\
\hline O. diantaeus H.D.K. & 19,3 & - \\
\hline O. cataphylla Dyar & 13,5 & - \\
\hline
\end{tabular}

Поява та благополучний розвиток преімагінальних фаз цих комарів до імаго переважно або значно пов'язані з рясністю зимових опадів та інтенсивністю заповнення талою водою весняних водойм.

Натомість, зима 2015 р. була малосніжною, а літо (за даними українського метеобюро) стало другим найтеплішим за весь період спостережень із 1881 p. (середня річна температура сягнула $21,6^{\circ} \mathrm{C}$, що на $2,9^{\circ} \mathrm{C}$ перевищує норму) та найпосушливішим (випало лише $30 \%$ опадів при нормі $68 \%$ ). Згідно $з$ даними метеостанції Канівського природного заповідника, середня річна температура у 2015 р. в межах заповідника перевищувала попередню на $1,5-2^{\circ} \mathrm{C}$, а кількість опадів (із січня до жовтня) була меншою на 150 мм (рис. 1, 2).
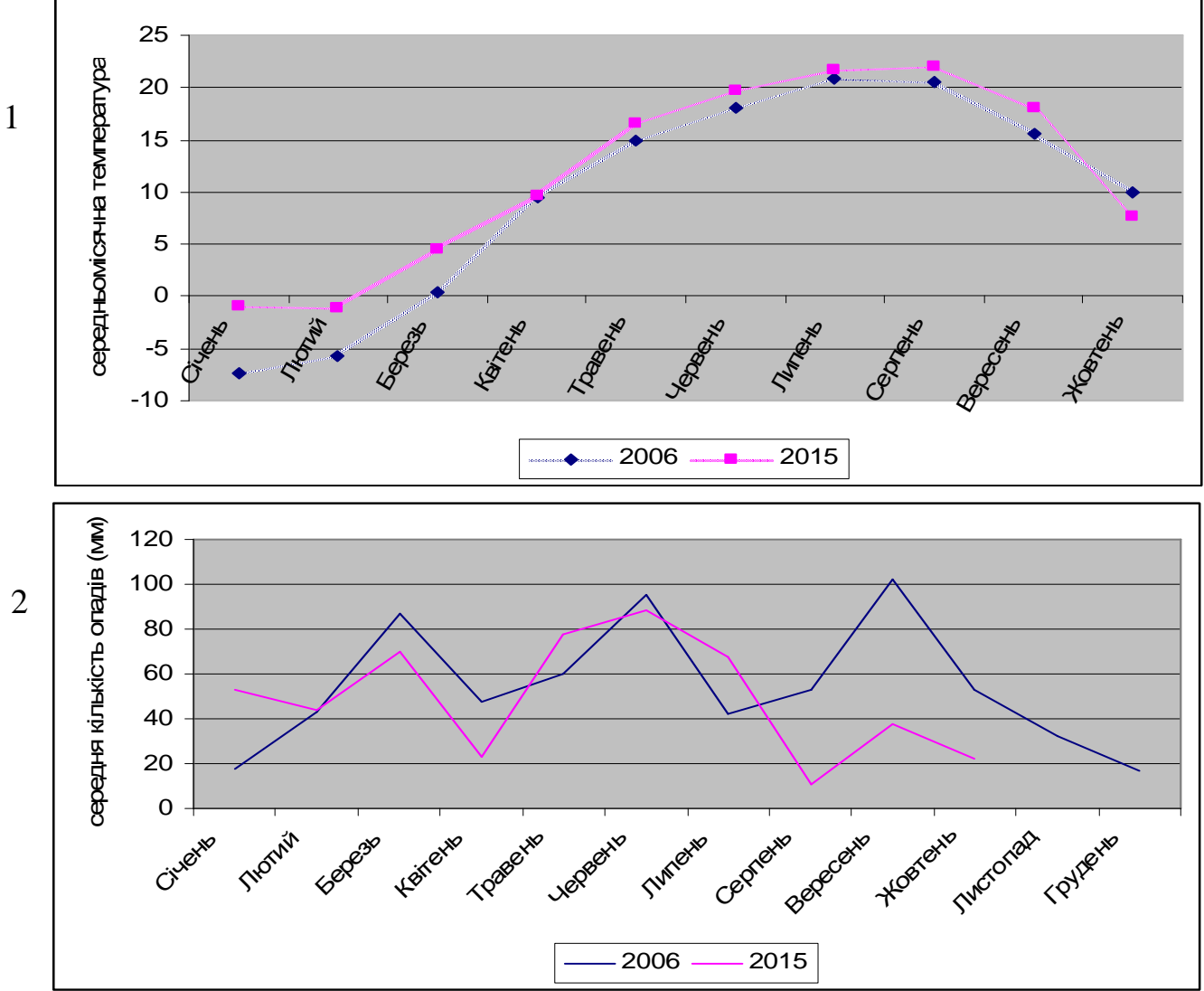

Рис. 1, 2. Зміни середньомісячної температури (1) та кількості опадів (2) у 2006 та 2015 рр. на території заповідника 
Особливості кліматичних умов цього року суттєво відобразилися на якісному й кількісному складі комарів у заповіднику. Зареєстровано 14 видів антропофільних комарів, які належать до шести родів: Anopheles, Culiseta, Coquillettidia, Ochlerotatus, Aedes, Culex. У зв’ язку з дефіцитом тимчасових водойм на домінуючі позиції вийшли комарі, розвиток личинок яких приурочений до напівпостійних (переважно постійних) водойм. Надзвичайно низькою чисельністю моноциклічних комарів із родів Aedes та Ochlerotatus можна пояснити відносно низьку загальну інтенсивність нападів комарів на людину (до 20 особин за 30 хв облікового відлову).

Суттєво змінився й список домінантів: вони всі були представлені поліциклічними видами. Абсолютно домінуючий у 2006 р. Ae. vexans (вид, що до цього завжди відрізнявся високою чисельністю на території заповідника $[2 ; 3])$ поступився місцем $C x$. modestus (див. табл. 1).

$C x$. modestus - евритопний, евригалінний, поліциклічний вид, личинки якого трапляються 3 кінця весни до пізньої осені в різного типу (переважно постійних) прісних та солонуватих водоймах різного походження, добре освітлених і багатих на органіку. Зимують запліднені самки. Відносне збільшення чисельності та домінуючий статус $C x$. modestus можна пояснити його широкою екологічною пластичністю - здатністю личинок розвиватися не лише в природних (напівпостійних $\mathrm{i}$ постійних), а й у полісапробних водоймах антропогенного походження.

Комарі виду Cs. alaskaensis на території заповідника відзначено нами вперше. Самки активно нападали на людину в різних стаціях - приміщеннях, на відкритих ділянках, як поблизу осель, так i на віддалених від житла людини територіях (Зміїні острови).

У межах ареалу Cs. alaskaensis є еврибіонтом і входить до переліку видів, преадаптованих до різких змін умов існування. Місця виплоду личинок приурочені до постійних водойм різного типу й походження. Зимують запліднені самки, а в теплі зими - i личинки.

Висновки та перспективи подальших досліджень. Проаналізовано кліматичні умови Канівського природного заповідника у 2006 і 2015 рp. і відзначено суттєву відмінність між температурним та гідрологічним режимами, що відобразилося на формуванні личинкових біотопів $\mathrm{i}$, як наслідок, призвело до суттєвих змін видового складу угруповань та інтенсивності нападу комарів на людину.

У 2006 р. на території досліджуваного регіону зареєстровано 17 видів кровосисних комарів, із трьох переважно моноциклічних родів (Anopheles, Ochlerotatus і Aedes). У 2015 р. перелік видів скоротився до 14 видів із шести, здебільшого поліциклічних родів (Anopheles, Culiseta, Coquillettidia, Ochlerotatus, Aedes та Culex).

Простежуються зміни в списках видів-домінантів: місце домінантного у 2006 р. літнього, поліциклічного Ae. vexans зайняв евритопний, евригалінний, поліциклічний $C x$. modestus. Також уперше на території заповідника зареєстровано еврибіонтний вид - Cs. alaskaensis.

Проведені дослідження показали, що видовий склад та чисельність кровосисних комарів на конкретній території кожного року пов’язані передусім із кліматичними (особливо гідрологічними) умовами.

Можна припустити, що глобальне потепління клімату й пов'язана 3 ним аридизація довкілля можуть спричинити суттєві та непередбачувані зміни у видовому складі й чисельності кровосисних комарів, а разом із ними - і в епідемічній ситуації в окремих регіонах.

\section{Джерела та література}

1. Гуцевич А. В. Фауна СССР. Насекомые двукрылые. Комары (семейство Culicidae) / А. В. Гуцевич, А. С. Мончадский, А. А. Штакельберг. - Л. : Наука, 1970. - Т. ІІІ, вып. 4. - 384 с.

2. Донец 3. С. К изучению кровососущих комаров поймы среднего течения р. Днепр в районе Канева / 3. С. Донец // Материалы к изучению фауны и экологии насекомых центральных районов Лесостепи Украины. - Киев, 1963. - С. 5-17.

3. Кілочицька Н. П. До вивчення епідеміологічної ситуації, пов'язаної з кровосисними комарами, в районі Канівського природного заповідника / Н. П. Кілочицька, В. А. Горобчишин // Збірник статей за матеріалами Всеукраїнської наукової конференції, присвяченої 175-річчю заснування кафедри зоології. - 15-18 верес. 2009 р. - Київ ; Канів, 2009. - С. 191-194.

4. Песенко Ю. А. Принципы и методы количественного анализа в фаунистических исследованиях / Ю. А. Песенко. - М. : Наука, 1982. - 288 с.

5. Разумейко В. Н. Методические рекомендации к изучению экологии кровососущих комаров / В. Н. Разумейко. - Симферополь, 2008. - 38 с. 
Килочицкая Наталия, Стеценко Ольга. Изменения количественного и качественного состава антропофильных видов кровососущих комаров Каневского природного заповедника. Каневский природный заповедник ежегодно является базой проведения летней учебной практики студентов. Одним из факторов опасности считаются комары - переносчики трансмиссивных заболеваний.

Климатические условия (температура, осадки) в сравниваемые годы на территории заповедника заметно отличались (2006 - влажный и умеренно теплый; а 2015 - сухой и жаркий). Следствием этого стали различия в формировании личиночных биотопов, повлекшие изменения видового состава и численности имаго комаров.

Если в 2006 г. на территории заповедника зарегистрировано 17 видов комаров из трех родов (преобладали моноциклические виды), то в 2015 г. количество видов составило 14, но из шести родов (с явным преобладанием полициклических видов).

Место доминирующего в 2006 г. Aedes vexans в 2015 г. занял Culex modestus. Также на территории заповедника впервые зарегистрирована Culiseta alaskaensis.

Ключевые слова: кровососущие комары; изменения климата; Каневский природный заповедник.

Kilochitska Nataliya, Stetsenko Olga. Qualitative and Quantitative Changes in Compositions of Species of Antropofilious Mosquitoes in the Kanev Natural Reserve. Kanev Nature Reserve is the base for the students' annual summer practical training. One of the risk factors are mosquitoes which are carriers of the vector-borne diseases.

During the years of comparison, the climatic conditions (e.g. temperature, precipitation) in the reserve were significantly different (in 2006 - humid and moderately warm, and in 2015 - dry and hot). As a consequence there appeared differences in formation of larval habitats, which induced changes in the composition of species and the quantity of adult mosquitoes.

While in 2006 the 17 species of mosquitoes from 3 genera (with domination of the monocyclic species) were recordedin the territory of the reserve, in 2015 the number of species became 14 from 6 genera (with a clear domination of the polycyclic species).

The dominant position of Aedes vexans in 2006 was taken by Culex modestus in 2015. Culiseta alaskaensis was also recorded in the territory of the reserve for the first time.

Key words: mosquitoes; climate change; Kanev Natural Reserve.

Стаття надійшла до редколегії 19.10.2015 p.

УДК 591.5: 594.1

Агнеса Стадниченко, Дмитро Вискушенко

\section{Вплив купрум сульфату водного середовища на частоту серцебиття перлівницевих (Mollusca, Bivalvia, Unionidae)}

Розглянуто вплив різних концентрацій $(0,1,1,10$ мг/дм³ $)$ купрум сульфату водного середовища на частоту серцебиття трьох видів перлівницевих. 3'ясовано, що за 0,1 мг/дм ${ }^{3}$ токсиканту у всіх досліджених молюсків ритм серцевих скорочень прискорюється. Зі збільшенням концентрації купрум сульфату у воді до 1, а потім до 10 мг/дм ${ }^{3}$ у цих тварин розвивається прогресуюча брадикардія.

Ключові слова: перлівницеві, купрум сульфат, частота серцебиття.

Постановка наукової проблеми та її значення. Сьогодні полютанти, які містять іони важких металів, є одними $з$ найпоширеніших забруднювачів як природного, так і штучного водного середовища. Це високотоксичні елементи [1], котрі дуже довго зберігаються в довкіллі. Вони наявні в стічних водах рудничного й шахтного виробництв, а також металообробних, машинобудівельних, хімічних, гальванічних підприємств. Нерідко іони міді $є$ компонентами й сільськогосподарських забруднень.

Гранично допустима їх концентрація у водоймах санітарно-гігієнічного призначення 0,1 мг/дм ${ }^{3}$, а у водоймах рибогосподарського призначення - 0,01 мг/дм². Варто зазначити, одначе, що значення другого 3 них установлено щодо риб, а через це нешкідливі для останніх концентрації токсикантів можуть виявитися згубними для інших гідробіонтів. До того ж у місцях випускання ски-

(ㄷ) Стадниченко А., Вискушенко Д., 2015 